\title{
Analisis Kebijakan Program Bina Keluarga Balita (BKB) Holistik Terintegrasi Dengan Posyandu dan PAUD di Kota Sawahlunto Tahun 2016
}

\author{
Santi Hariani ${ }^{1}$, Masrul $^{2}$, Fauziah Elytha ${ }^{3}$
}

\begin{abstract}
Abstrak
Sumber daya manusia, dana, sarana dan prasarana kelompok BKB holistik terintegrasi dengan Posyandu dan PAUD di Kota Sawahlunto belum memadai. Capaian terhadap Kelompok BKB aktif dan keluarga balita aktif ke kelompok BKB Holistik terintegrasi masih dibawah target BKKBN. Tujuan penelitian adalah mengetahui pelaksanaan Program BKB holistik terintegrasi dengan Posyandu dan PAUD sesuai dengan Peraturan Presiden no 60 tahun 2013 di Kota sawahlunto. Metode penelitian menggunakan pendekatan kualitatif dan merupakan studi kebijakan (Policy study). informan penelitian berjumlah 26 orang. Teknik pengumpulan data melalui observasi, wawancara mendalam, focus grup discussion dan telaah dokumen. Analisa dilakukan sebelum, selama dan sesudah dilapangan penelitian. Hasil penelitian pada komponen masukan yaitu sumber daya manusia, dana, sarana prasarana kelompok BKB belum sesuai dengan ketentuan. Komponen proses yaitu belum berjalannya Pokjanal kecamatan dan desa untuk binaan, monitoring dan evaluasi. Komponen keluaran yaitu capaian kelompok BKB aktif dan keluarga balita aktif belum memenuhi standar minimal BKKBN, rendahnya pengetahuan kader BKB dan keluarga balita terhadap program BKB holisitik terintegrasi dengan Posyandu dan PAUD di Kota Sawahlunto. Simpulan pelaksanaan program BKB holistik terintegrasi dengan Posyandu dan PAUD Kota Sawahlunto tahun 2016 belum seluruhnya sesuai peraturan dan harapan yaitu pada komponen masukan, proses dan Keluaran.
\end{abstract}

Kata kunci: kebijakan, pelaksanaan, program BKB holistik terintegrasi dengan Posyandu dan PAUD

\begin{abstract}
Human resources, funds, facilities and infrastucture of Todler Family Care Managemen (BKB) holisticintegrated with Posyandu and PAUD in the city of Sawahlunto are not insufficient. Coverage in active group BKB and active todler family in the BKB Holistic Integrative group does not reach the BKKBN target. The objective of this study was to know the implementation of a holistic-integrated -BKB Program with Posyandu and Early Childhood Program (PAUD) in the city of Sawahlunto year 2016, according to the Presidential Regulation. 60 of 2013. Method the research used a qualitative methods and was a policy study. Informants of the research are 26 peoples. Collecting data technic with observation, in-depth interviews, focus group discussion, and a document review. Data were analized before, during and after the research field. Result in the input component, human resources, funds, facilities and infrastructure of the BKB group have not yet been determined. In the proses component the Support, monitoring and evaluation insub-Distric and villagesub-district operational team work (Pokjanal) has not progresed. In output aspect: the achievement of active BKB group and active todler family has not met BKKBN minimum standards, low knowledge of BKB cadres and todler family againts the Integrated Holistic BKB Program with Posyandu and PAUD in thecity of Sawahlunto.Conclusion the implementation program of integrated Holistic BKB with Posyandu and PAUD in the city of Sawahlunto year 2016 not has beenentirely in accordance with the regulation in the implementation of input, process and output components.
\end{abstract}

Keywords: policy, implementation, integrative holistic BKB program with Posyandu and PAUD 
Affiliasi penulis: 1. BKKBN Provinsi Sumbar. 2. Bagian Gizi Fakultas Kedokteran Universitas Andalas Padang (FK Unand), 3. Fakultas Kesehatan Masyarakat Unand Padang

Korespondensi: santihariani1981@gmail.com Telp: 085264173008

\section{PENDAHULUAN}

Pembangunan Sumber Daya Manusia (SDM) harus dimulai sejak usia dini yang dimulai dari dalam kandungan sampai lanjut usia. Salah satu tahap yang amat penting adalah tahap janin sampai anak berusia 2 tahun (1000 hari pertama kehidupan) yang disebut golden age period karena pada usia ini perkembangan otak anak mencapai $80 \%$ dimana perlu pengembangan aspek dalam diri anak secara fisik, emosional, sosial, dan pengetahuan intelektualnya. ${ }^{1}$

Diperkirakan lebih dari 200 juta anak balita di negara berkembang gagal mencapai potensi perkembangan disebabkan masalah kemiskinan, malnutrisi, atau lingkungan yang tidak mendukung, sehingga mempengaruhi perkembangan kognitif, motorik, emosi, dan sosial anak. Beberapa hal yang perlu diperhatikan dalam pertumbuhan dan perkembangan balita meliputi gizi yang baik, stimulasi yang memadai dan terjangkaunya pelayanan kesehatan berkualitas termasuk deteksi dini serta intervensi dini penyimpangan tumbuh kembang balita. ${ }^{2}$

Upaya pemerintah untuk mengatasi permasalahan pertumbuhan dan perkembangan pada balita adalah dengan mengintegrasikan kegiatan Bina Keluarga Balita (BKB), Pos Pelayanan Terpadu (Posyandu) dan Pendidikan Anak Usia Dini (PAUD). ${ }^{3}$ Kondisi kegiatan BKB, Posyandu dan PAUD selama ini terkesan berjalan sendiri-sendiri sehingga perlu adanya kebijakan untuk mensinergiskannya sehingga tercapai tujuan pendidikan yaitu "Anak Indonesia Sehat, Cerdas, Bercita-cita Tinggi dan Berakhlak Mulia" yang berdimensi holistic. ${ }^{4}$

Kebijakan adalah sejumlah aktifitas pemerintah untuk memecahkan masalah di masyarakat, baik secara langsung maupun melalui berbagai lembaga yang mempengaruhi kehidupan masyarakat. BKB (Bina Keluarga Balita) adalah kegiatan bersama yang dilakukan oleh kader dengan orang tua atau anggota keluarga lainnya yang mempunyai anak balita. ${ }^{5}$

Pengembangan anak usia dini holistik terintegrasi adalah kegiatan yang dilakukan berdasarkan pemahaman untuk memenuhi kebutuhan dasar anak yang beragam, saling terkait secara simultan dan sistematis. Posyandu adalah kependekan dari Pos Pelayanan Terpadu merupakan kegiatan kesehatan dasar yang diselenggarakan dari, oleh, dan untuk masyarakat yang dibantu oleh petugas kesehatan di suatu wilayah kerja Puskesmas, dimana program ini dapat dilaksanakan di balai dusun, balai kelurahan, maupun tempat lain yang mudah didatangi oleh masyarakat. ${ }^{6}$ Pelayanan holistik terintegrasi adalah pelayanan secara utuh, menyeluruh dan terintegrasi dalam rangka memenuhi kebutuhan dasar anak. Dalam pelaksanaan keterpaduan kegiatan kegiatan di Posyandu menggunakan lima meja dimana pada meja pertama perlu integrasi antara kader BKB, Posyandu dan PAUD untuk pendaftaran sasaran yang hadir. Dimeja kedua dilakukan penimbangan bagi kader Posyandu dan pemantauan perkembangan oleh kader BKB. Dimeja ketiga dilakukan pencatatan KMS oleh kader Posyandu dan KKA oleh kader BKB. Meja keempat kader posyandu melakukan penyuluhan dan stimulasi serta deteksi menggunakan buku KIA, kader BKB memberikan penyuluhan stimulasi perkembangan anak dan kegiatan BKB sedangkan kader PAUD/ Guru kontrak memberikan penyuluhan pendidikan dini prasekolah. Dimeja kelima dilakukan pelayanan kesehatan berupa imunisasi, KIA termasuk SDDTK dan KB, penanggulangan masalah gizi dengan memberikan makanan tambahan. ${ }^{7}$

\section{METODE}

Rancangan penelitian studi kebijakan (Policy Study) dengan metode Kualitatif menggunakan tehnik wawancara mendalam dan FGD (Fokus Grup Diskusi). ${ }^{9}$ Observasi langsung di lokasi penelitian serta telaaah dokumen untuk mendapatkan informasi yang mendalam tentang analisis kebijakan program Bina Keluarga Balita holistik terintegrasi dengan Posyandu dan PAUD di Kota Sawahlunto. Penelitian telah di laksanakan di kelompok BKB holistik terintegrasi dengan Posyandu dan PAUD dan instansi terkait di Kota Sawahlunto pada bulan Mei sampai dengan Juli 2016.

Pemilihan informan secara Purposive Sampling, instrumen penelitian adalah pedoman wawancara mendalam dan FGD, Panduan Observasi dan daftar telaah dokumen, catatan lapangan serta 
tape recorder. Tehnik pengumpulan data menggunakan triangulasi yaitu wawancara mendalam, observasi dan dokumentasi. ${ }^{10}$

Analisis data dilakukan pada waktu bersamaan degan proses pengumpulan data berlangsung. Reduksi data atau merangkum seluruh data, melaui seleksi, pengkodean, membuat kategorisasi dan membuat catatan kaki dan disajikan dalam bentuk teks yang naratif, secara sistematis kemudian disimpulkan sesuai dengan rumusan masalah dan tujuan penelitian dan dilakukan pemeriksaan validitas data penelitian untuk menghasilkan data yang lengkap dan valid. ${ }^{11}$

\section{HASIL}

Penelitian ini dilakukan untuk mengetahui komponen masukan yaitu kebijakan, sumber daya manusia, dana dan sarana prasarana, mengetahui komponen proses yaitu perencanaan dan pelaksanaan, monitoring evaluasi dan komponen keluaran yaitu cakupan jumlah kelompok yang aktif,cakupan keluarga balita aktif, serta pengetahuan kader dan orang tua dalam kegiatan BKB holistik terintegrasi dengan Posyandu dan PAUD di Kota Sawahlunto tahun 2016.

\section{Komponen Masukan}

\section{Kebijakan}

Tabel 1. Kebijakan kegiatan BKB holistik terintegrasi dengan Posyandu dan PAUD Kota Sawahlunto 2016

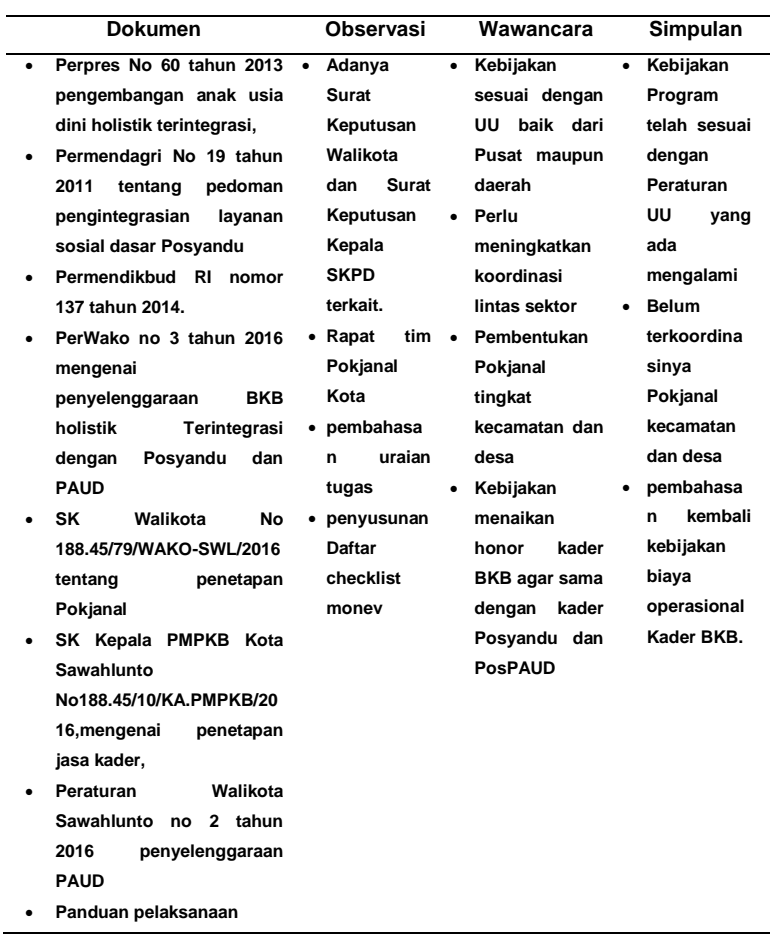

Hasil telaah dokumen, observasi dan wawancara mendapatkan hasil penelitian bahwa sudah ada kebijakan Program Bina Keluarga berencana (BKB) holistik terintegrasi dengan Posyandu dan PAUD di Kota Sawahlunto tahun 2016 mulai dari peraturan presiden, peraturan menteri dalam negeri, undang undang yang mengatur serta didukung oleh surat keputusan Walikota dan Peraturan kepala SKPD terkait namun dalam pelaksanaannya kurangnya koordinasidan integrasi antara Pemerintah Pusat, daerah dan SKPD terkait serta perlunya pembahasan kembali terkait kebijakan pembiayaan operasional kader BKB yang lebih rendah dibandingkan kader Posyandu dan PAUD.

\section{Sumber Daya Manusia}

Tabel 2. SDM BKB holistik terintegrasi dengan Posyandu dan PAUD Kota Sawahluno tahun 2016.

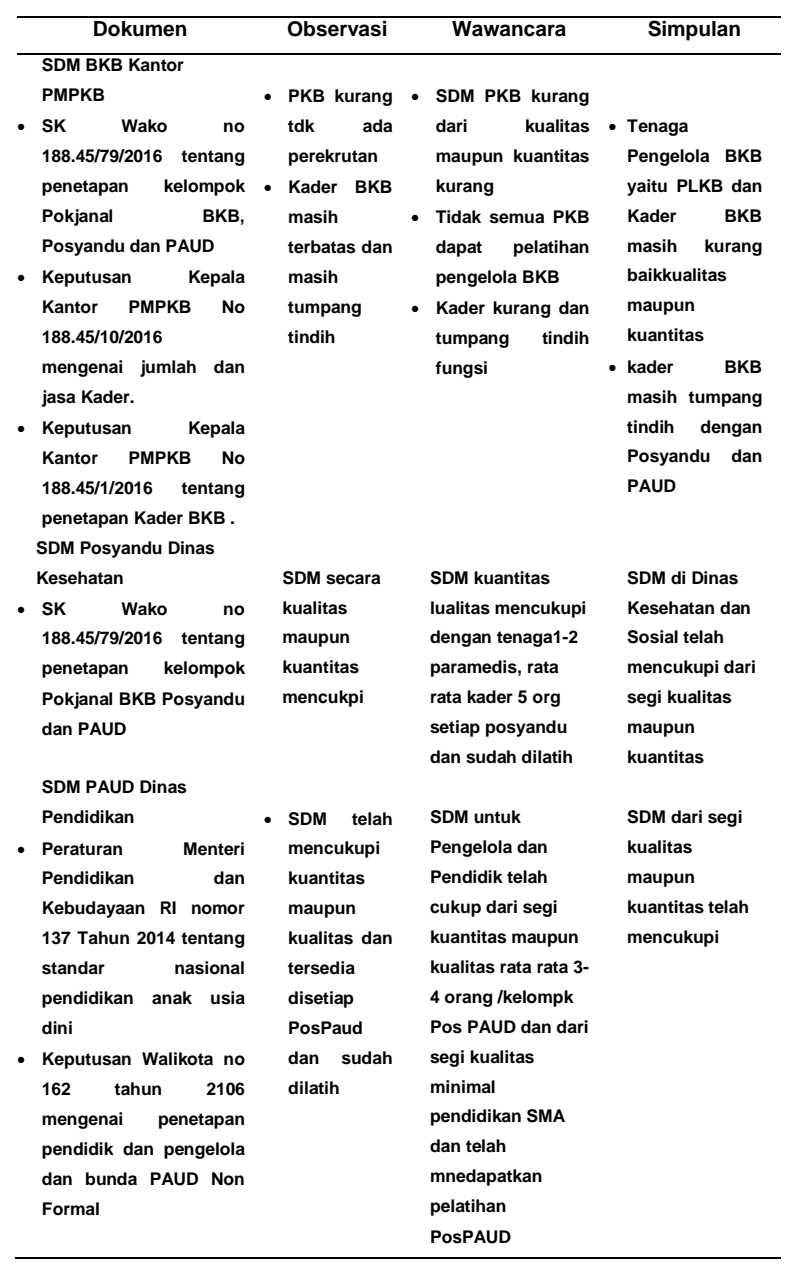

Hasil telaah dokumen, observasi dan wawancara penelitian sumber daya manusia Program Bina Keluarga Balita (BKB) terintegrasi dengan Posyandu dan PAUD di Kota Sawahlunto tahun 2016 
untuk pengelola BKB masih kurang dibandingkan pengelola Posyandu dan PAUD dan untuk tenaga kader BKB masih merangkap sebagai kader Posyandu, Kader dasawisma dan lainnya.Perlunya penambahan jumlah pengeola kelompok BKB dan pelatihan bagi pengelola dan kader BKB dalam pelaksanaan BKB holistik terintegrasi di Posyandu dan PAUD.

\section{Dana}

Tabel 3. Dana Kegiatan BKB Holistik Terintegrasi dengan Posyandu dan PAUD Kota Sawahlunto 2016

\begin{tabular}{|c|c|c|c|}
\hline Dokumen & Observasi & Wawancara & Simpulan \\
\hline 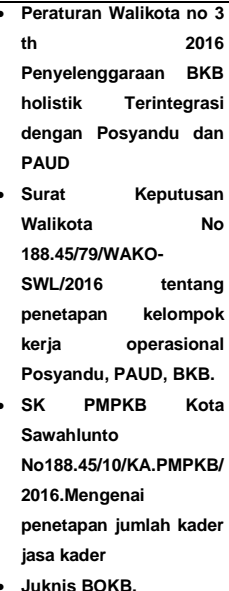 & 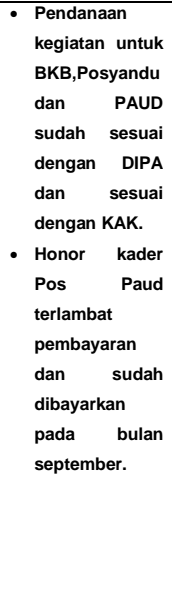 & $\begin{array}{l}\text { - Pencairan dana } \\
\text { APBD sudah } \\
\text { sesuai dengan } \\
\text { DIPA,pendanaa } \\
\text { n BKB } \\
\text { mengalami } \\
\text { penurunan } \\
\text { - Operasional } \\
\text { Kader Pos } \\
\text { PAUD tertunda } \\
\text { menunggu } \\
\text { perubahan } \\
\text { anggaran }\end{array}$ & $\begin{array}{l}\text { Dana kegiatan } \\
\text { BKB holistik } \\
\text { terintegrasi } \\
\text { dengan } \\
\text { Posyandu } \\
\text { PAUD tersedia } \\
\text { di APBD dan } \\
\text { APBN namun } \\
\text { mengalami } \\
\text { penurunan dan } \\
\text { masih kurang } \\
\text { diharapkan } \\
\text { teranggarkan di } \\
\text { dana Desa dan } \\
\text { swadaya } \\
\text { Masyarakat }\end{array}$ \\
\hline
\end{tabular}

Hasil telaah dokumen, observasi dan wawancara penelitian dapat dilihat bahwa untuk pendanaan Program PAUD dan Posyandu telah mencukupi sedangkan untuk pendanaan kegiatan BKB masih kurang yaitu dari dukungan operasional kader yang jumlahnya lebih rendah dari Posyandu dan diberikan hanya untuk ketua kelompok kader BKB saja.Untuk itu diharapkan kerjasama dan dukungan lintas sektoral serta pemanfaatan dana desa dan perlunya dukungan swadaya masyarakat.

\section{Sarana dan Prasarana}

Tabel 4. Sarana prasarana program BKB holistik terintegrasi dengan Posyandu dan PAUD di Kota Sawahlunto tahun 2016.

\begin{tabular}{|c|c|c|c|}
\hline Dokumen & Observasi & Wawancara & Simpulan \\
\hline $\begin{array}{l}\text { Perka BKKBN, } \\
2014 \text { tentang } \\
\text { pelaksanaan BKB } \\
\text { yang terintegrasi } \\
\text { dengan Posyandu } \\
\text { dan PAUD } \\
\text { - Permendikbud } \\
\text { Republik } \\
\text { Indonesia Nomor } \\
137 \text { Tahun 2014 } \\
\text { tentang standar } \\
\text { nasional } \\
\text { pendidikan anak } \\
\text { usia dini }\end{array}$ & 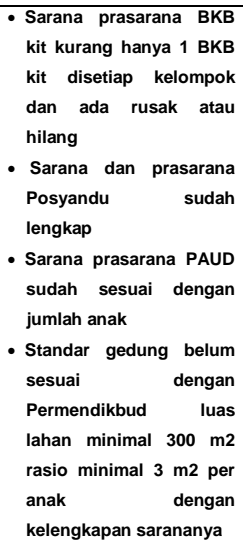 & $\begin{array}{l}\text { - Sarana dan } \\
\text { prasarana } \\
\text { untuk } \\
\text { pelaksaan BKB } \\
\text { Holistik } \\
\text { terintegrasi } \\
\text { dengan } \\
\text { Posyandu dan } \\
\text { PAUD di kota } \\
\text { Sawahlunto } \\
\text { belum lengkap } \\
\text { dan memadai }\end{array}$ & $\begin{array}{l}\text { - Sarana dan } \\
\text { prasarana } \\
\text { untuk } \\
\text { pelaksanaan } \\
\text { BKB belum } \\
\text { lengkap dan } \\
\text { memadai } \\
\text { - sarana } \\
\text { gedung } \\
\text { belum } \\
\text { memenuhi } \\
\text { standar }\end{array}$ \\
\hline
\end{tabular}
wawancara penelitian dapat dilihat bahwa sarana dan prasarana kegiatan PAUD dan Posyandu sudah lengkap namun untuk sarana prasarana kelompok BKB masih kurang yaitu hanya 1 BKB kit untuk1 kelompok BKB dan ditemukan ada yang rusak dan hilang. BKB kit diharapkan ada 5 buah disetiap kelompok sesuai dengan kelompok umur. ${ }^{12}$ Gedung pelaksanaan BKB Paud dan Posyandu juga belum memenuhi standar yaitu ukuran rasio minimal $3 \mathrm{~m}^{2}$ per anak. Perlu penambahan BKB Kit disetiap kelompok $\mathrm{BKB}$ dan pengembangan gedung kegiatan $\mathrm{BKB}$ holistik terintegrasi dengan Posyandu dan PAUD. ${ }^{7}$

\section{Komponen Proses}

\section{Perencanaan}

Tabel 5. Perencanaan kegiatan BKB Holistik terintegrasi dengan Posyandu dan PAUD di Kota Sawahlunto tahun 2016

\begin{tabular}{|c|c|c|c|}
\hline Dokumen & Observasi & Wawancara & Simpulan \\
\hline $\begin{array}{l}\text { Perka BKKBN, } \\
2014 \text { tentang } \\
\text { pelaksanaan } \\
\text { BKB yang } \\
\text { terintegrasi } \\
\text { dengan } \\
\text { Posyandu dan } \\
\text { PAUD } \\
\text { Kerangka } \\
\text { Acuan kinerja }\end{array}$ & $\begin{array}{l}\text { - } \text { kerangka acuan } \\
\text { kinerja Program BKB, } \\
\text { Posyandu dan paud, } \\
\text { - Pertemuan lintas } \\
\text { sector pengelola } \\
\text { program } \\
\text { BKB,Posyandu dan } \\
\text { PAUD, } \\
\text { - Rapar pembentukan } \\
\text { tim Pokjanal tingkat } \\
\text { kota, pembinaan } \\
\text { - Jadwal dan } \\
\text { monitoring Pokjanal } \\
\text { evaluasi tim Pota. } \\
\text { Kota. }\end{array}$ & $\begin{array}{l}\text { - Perencanaan } \\
\text { Program tertuang } \\
\text { didalam kerangka } \\
\text { acuan Kerja. } \\
\text { - Pertemuan lintas } \\
\text { sektor terkait } \\
\text { dalam } \\
\text { - Penyusunan } \\
\text { agenda kegiatan } \\
\text { sosialisasi, } \\
\text { pembinaan } \\
\text { monitoring, dan } \\
\text { evaluasi } \\
\text { - Jadwal lomba } \\
\text { kader BKB dan } \\
\text { Posyandu } \\
\text {,jambore PAUD. }\end{array}$ & $\begin{array}{l}\text { - Perencanaan } \\
\text { Program BKB } \\
\text { holistik } \\
\text { terintegrasi } \\
\text { dengan } \\
\text { Posyandu dan } \\
\text { PAUD tertuang } \\
\text { dalam kerangka } \\
\text { acuan kinerja } \\
\text { - Terbentuknya } \\
\text { tim pokjanal } \\
\text { sebagai wujud } \\
\text { kerjasama lintas } \\
\text { sektoral, }\end{array}$ \\
\hline
\end{tabular}


Hasil telaah dokumen, observasi dan wawancara perencanaan program BKB holistik terintegrasi dengan Posyandu dan PAUD di Kota Sawahlunto dapat dilihat bahwa perencanaan sudah dilaksanakan diawal tahun yaitu menyusun kerangka acuan kinerja dilanjutkan dengan pertemuan lintas sektor terkait dengan pokjanal dalam menyusun jadwal kegiatan, jadwal pembinaan monitoring dan evaluasi pelaksanaan kegiatan BKB Holistik terintegrasi dengan Posyandu dan PAUD. Perlunya penguatan lintas sektor dalam mensinergiskan kegiatan, perlunya pendekatan dengan pengambilan kebijakan dan terlibat dalam musrembang desa dalam penyusunan perencanaan dan pemanfaatan dana desa. $^{5}$

\section{Prosedur Pelaksanaan}

Hasil telaah dokumen, observasi dan wawancara perencanaan program BKB holistik terintegrasi dengan Posyandu dan PAUD di Kota Sawahlunto tahapan persiapan telah sesuai dengan kerangka acuan kinerja dan jadwal yang ada namun dalam pelaksanaannya masih banyak kader yang tidak mengisi kartu kembang anak disebabkan pemahaman kader dan keluarga yang kurang. Perlunya peningkatan pengetahuan kader BKB dalam pelaksanaan kegiatan BKB holistik terintegrasi dengan Posyandu dan PAUD.

Tabel 6. Prosedur pelaksanaan program BKB holistik terintegrasi dengan Posyandu dan PAUD Kota Sawahlunto tahun 2016

\begin{tabular}{|c|c|c|c|}
\hline Dokumen & Observasi & Wawancara & Simpulan \\
\hline $\begin{array}{l}\text { - Perka BKKBN } 2014 \\
\text { - Permendikbud No } 137 \\
\text { tahun } 2014 \\
\text { - Peraturan Walikota nomor } \\
3 \text { tahun } 2016 \\
\text { - Surat Keputusan Walikota } \\
\text { No } 188.45 / 79 / \text { WAKO- } \\
\text { SWL/2016 tentang } \\
\text { penetapan kelompok kerja } \\
\text { operasional } \\
\text { - Surat Keputusan Kepala } \\
\text { PMPKB Kota } \\
\text { SawahluntoNo188.45/10/K } \\
\text { A.PMPKB/2016 tentang } \\
\text { penetapan kader } \\
\text { - SK PMPKB } \\
\text { No188.45/1.a/KaPMPKB/20 } \\
\text { 16 } \\
\text { - Peraturan Walikota } \\
\text { Sawahlunto nomor } 2 \text { tahun } \\
\text { 2016 tentang } \\
\text { penyelenggaraan } \\
\text { Pendidikan anak usia dini, }\end{array}$ & $\begin{array}{l}\text { prosedur } \\
\text { pelaksanaan } \\
\text { dimulai: } \\
\text { 1. persiapan } \\
\text { 2. penyusunan } \\
\text { KAK } \\
\text { 3. penyusunan } \\
\text { jadwal, } \\
\text { 4. penentuan } \\
\text { pengelola dan } \\
\text { Pembina } \\
\text { wilayah, } \\
\text { 5. Jadwal } \\
\text { pelaksanaan } \\
\text { kegiatan Untuk } \\
\text { kegiatan } \\
\text { pembinaan dan } \\
\text { Monev }\end{array}$ & $\begin{array}{l}\text { Prosedur } \\
\text { pelaksanaa } \\
\text { n sudah } \\
\text { sesuai } \\
\text { dengan } \\
\text { KAK } \\
\text { - Jadwal } \\
\text { kegiatan } \\
\text { Posyandu, }\end{array}$ & $\begin{array}{l}\text { - Prosedur } \\
\text { Pelaksanaan } \\
\text { Program BKB } \\
\text { holistik } \\
\text { terintegrasi } \\
\text { dengan } \\
\text { Posyandu dan } \\
\text { PAUD } \\
\text { berdasarkan } \\
\text { KAK } \\
\text { - petunjuk teknis } \\
\text { yang ada, } \\
\text { - penyusunan } \\
\text { jadwal kegiatan, } \\
\text { - SK pengelola } \\
\text { dan pelaksana } \\
\text { Pokjanal yang } \\
\text { terkait }\end{array}$ \\
\hline
\end{tabular}

\section{Monitoring dan Evaluasi}

Tabel 7. Monitoring dan evaluasi program BKB holistik terintegrasi dengan Posyandu dan PAUD di Kota Sawahlunto tahun 2016.

\begin{tabular}{|c|c|c|c|}
\hline Dokumen & Observasi & Wawancara & Simpulan \\
\hline $\begin{array}{l}\text { Peraturan Walikota no } 3 \\
\text { tahun } 2016 \text { mengenai } \\
\text { penyelenggaraan BKB } \\
\text { holistik Terintegrasi } \\
\text { dengan Posyandu dan } \\
\text { PAUD } \\
\text { SK Walikota No } \\
\text { 188.45/79/WAKO-SWL/2016 } \\
\text { tentang penetapan } \\
\text { kelompok kerja } \\
\text { operasional Posyandu, } \\
\text { BKB,Paud } \\
\text { SK Kepala PMPKB Kota } \\
\text { Sawahlunto } \\
\text { No188.45/10/KA.PMPKB/20 } \\
\text { 16,mengenai penetapan } \\
\text { jumlah kader jasa kader, } \\
\text { SK Kepala PMPKB Kota } \\
\text { Sawahlunto } \\
\text { tahun2016,No188.45/1.a/Ka } \\
\text { PMPKB } \\
\text { - Jadwal pertemuan } \\
\text { Pokjanal }\end{array}$ & $\begin{array}{l}\text { - Buku } \\
\text { pencatatan } \\
\text { pelaporan } \\
\text { kader } \\
\text { Posyandu, } \\
\text { BKB, PAUD. } \\
\text { - Jadwal } \\
\text { monitoring dan } \\
\text { evaluasi } \\
\text { - Blanko } \\
\text { monitoring dan } \\
\text { evaluasi } \\
\text { - Tim Pokjanal } \\
\text { Kecamatan dan } \\
\text { desa tidak } \\
\text { berjalan } \\
\text { - Daftar hadir tim } \\
\text { monitoring dan } \\
\text { evaluasi } \\
\text { - Dokumentasi/L } \\
\text { aporan } \\
\text { kegiatan tidak } \\
\text { ada }\end{array}$ & $\begin{array}{l}\text { Monitoring dan } \\
\text { evaluasi yang } \\
\text { dilakukan oleh } \\
\text { pengelola BKB, } \\
\text { Posyandu dan } \\
\text { PAUD sudah } \\
\text { sesuai dengan } \\
\text { petunjuk teknis } \\
\text { menggunakan } \\
\text { daftar checklist } \\
\text { formulir } \\
\text { dengan } \\
\text { melakukan } \\
\text { feed back }\end{array}$ & $\begin{array}{l}\text { - Monitoring } \\
\text { dan evaluasi } \\
\text { dilakukan } \\
\text { sesuai } \\
\text { dengan } \\
\text { ketentuan } \\
\text { atau juknis } \\
\text { yang ada } \\
\text { - Pokjanal } \\
\text { kecamatan } \\
\text { dan desa } \\
\text { tidak } \\
\text { berjalan } \\
\text { - Tidak ada } \\
\text { laporan } \\
\text { kegiatan } \\
\text { monitoring } \\
\text { dan evaluasi }\end{array}$ \\
\hline
\end{tabular}

Hasil telaah dokumen, observasi dan wawancara bahwa pelaksanaan program BKB Holistik terintegrasi dengan Posyandu dan Paud sudah sesuai dengan petunjuk teknis dengan menggunakan formulir/daftar checklist dan melakukan feedback langsung dilapangan namun monitoring evaluasi hanya dilakukan oleh tim Pokjanal Kota dan tidak dilaksanakan oleh pokjanal kecamatan dan desa. Perlunya pembinaan berkesinambungan dari Pokjanal provinsi, kota, kecamatan dan desa agar pelaksanaan program berjalan dengan kualitas yang diharapkan.

\section{Komponen Keluaran}

Tabel 8. Out Put capaian kelompok BKB dan keluarga balita aktif yang mengikuti program BKB holistik terintegrasi.

\begin{tabular}{|c|c|c|c|c|}
\hline & Dokumen & Observasi & Wawancara & Simpulan \\
\hline & $\begin{array}{l}\text { Laporan } \\
\text { R/II/BKB } \\
\text { yang diinput } \\
\text { dari kader } \\
\text { BKB setiap } \\
\text { bulannya }\end{array}$ & $\begin{array}{l}\text { - } \text { Buku pencatatan } \\
\text { pelaporan kader } \\
\text { Posyandu, BKB, PAUD. } \\
\text { - Laporan dallap BKKBN } \\
\text { Sumbar dengan hasil } \\
\text { kelompok BKB aktif } \\
87.7 \% \text { keluarga balita } \\
\text { yang berkunjung } 77,5 \% .\end{array}$ & $\begin{array}{l}\text { Output } \\
\text { kegiatan dilihat } \\
\text { dari jumlah } \\
\text { kunjungan atau } \\
\text { kegiatan } \\
\text { pertemuan dan } \\
\text { jumlah orang } \\
\text { tua balita yang } \\
\text { hadir }\end{array}$ & $\begin{array}{l}\text { Capaian kegiatan } \\
\text { BKB holistik } \\
\text { terintegrasi dilihat } \\
\text { dari laporan } \\
\text { Dallap R/ll/BKB } \\
\text { yang dikirim } \\
\text { setiap bulan oleh } \\
\text { kab/kota }\end{array}$ \\
\hline
\end{tabular}

Hasil telaah dokumen, observasi, wawancara dapat disimpulkan bahwa capaian kelompok BKB aktif dan keluarga aktif ikut kegiatan BKB masih belum memenuhi target hal ini disebabkan oleh pemahaman kader BKB yang masih rendah, terbatasnya jumlah 
kader BKB dan pengelola BKB serta keterlambatan pengiriman laporan $\mathrm{R} / \mathrm{II} / \mathrm{BKB}$ ke petugas lapangan serta masih kurangnya dokumentasi dan pelaporan kegiatan BKB holistik terintegrasi dengan Posyandu dan PAUD.

Output pengetahuan dan pemahaman kader dan keluarga balita tentang Program BKB holistiik terintegrasi dengan Posyandu dan PAUD

Hasil Focus Grup Discusion (FGD) yang dilakukan kepada klader dan keluarga balita ddapatkan bahwa kader BKB belum paham dan mengerrti tentang penyuluhan perkembangan tumbuh kembang anak, pengisian kartu kembang anak dan cara permainan edukatif sesuai kelompok umur. Dari diskusi yang dilakukan pada orang tua balita bahwa juga atidak memahami pengsiisan KKA dan permainan edukatif sesuaidengan kelompok umur. Perlu peningkatan pengetahuan pengelola BKB,kader BKB dan penyuluhan kepada keluarga balita serta perlunya mengitegrasikan kegiatan pembinaan, sosialisasi dan pelatihankader oleh lintas sektor terkait.

\section{SIMPULAN}

Pelaksanaan program BKB holistik terintegrasi dengan Posyandu dan PAUD sudah didukung oleh kebijakan baik dari peraturan presiden, menteri, Undang Undang serta peraturan walikota dan SKPD terkait. Sumber daya manusia masih kurang pada pengelola BKB dan pelaksana dilapangan serta sarana prasarana dan dana untuk kelompok BKB yang masih rendah dibandingkan dan pelaksanaan PAUD dan posyandu.

Capaian program BKB holistik terintegrasi dengan Posyandu dan PAUD di Kota Sawahlunto tahun 2016 masih belum memenuhi target disebabkan karena kurangnya pemahaman pengelola Kelompok $B K B$, kader BKB serta keluarga dan masyarakat yang belum paham tentang pentingnya program BKB.

\section{SARAN}

Ada pembahasan kembali kebijakan terkait dengan pembiayaan operasional kader BKB, melakukan pelatihan dengan berintegrasi kepada lintas sektoral kepada pengelola kelompok BKB,dan kader BKB serta peningkatan promosi dan edukasi kepada masyarakat terutama kepada keluarga balita mengenai pertumbuihan dan perkembangan balita serta pomantauannya dengan menggunakan kartu kembang anak serta alat permainan edukatif sesuai pada kelompok umur. ${ }^{12}$

\section{UCAPAN TERIMAKASIH}

Terimakasih kepada Dinas Kesehatan Sawahlunto, BKKBN Sawahlunto, Kantor Pemberdayaan masayarakat perempuan, dinas Sosial kota Sawahlunto, Dinas Pendidikan Kebudayaan dan Olahraga kota Sawahlunto dan instansi terkait beserta semua pihak yang sudah ikut membantu penulis dalam menyelesaikan tulisan ini.

\section{DAFTAR PUSTAKA}

1 Badan Kependudukan Keluarga Berencana Nasional (BKKBN). Pedoman Pelaksanaan Program Bina Keluarga Balita Holistik Terintegratif. Jakarta; BKKBN; 2013.

2. Pusat Data dan Informasi Departemen Kesehatan $\mathrm{RI}$ (Depkes RI). Pedoman umum pengelolaan Posyandu. Jakarta: Depkes RI; 2006.

3. Dema Y. Analisis pembelajaran holistik integratif pada anak-anak di taman kanak kanak negeri pembina Grogol Kabupaten Kediri. Jurnal Pendidikan. 2016;2(1):112-8.

4. Badan Kependudukan Keluarga Berencana Nasional (BKKBN). Bahan penyuluhan bina keluarga balita bagi kader, menjadi orang tua hebat buku 3. Jakarta: BKKBN; 2014.

5. Leo A. Dasar- dasar Kebijakan Publik. Bandung: CV Alfabeta; 2009.hlm.96-8. 
6. Badan Kependudukan Keluarga Berencana Nasional (BKKBN). Pengasuhan dan pembinaan tumbuh kembang anak. Jakarta: BKKBN; 2013.

7. Adriana D. Tumbuh kembang dan terapi bermain pada anak. Jakarta: Salemba Medika; 2011.hlm.18

8. Afniwati. Analisis kebijakan pelayanan kesehatan dasar gratis di kota Padang. Padang;2011.hlm.1215.
9. Helmawati. Mengenal dan memahami PAUD. Bandung: Rosdakarya; 2015.hlm.32.

10. Sugiono. Metodologi penelitian administratif. Bandung: EGC; 2014.hlm.42

11. Budiarto E. Pengantar epidemiologi. Jakarta: EGC; 2002.hlm.52-3.

12. Widati A. Pengaruh terapi Bermain. Jakarta, EGC; 2012.hlm.29-30. 